DOI:

UDC 621.793 .6

D. Sereda, Candidate of Technical Sciences (Ph. D.), serededb@ukr.net

Dniprovsky State Technical University, Kamianske

\title{
MODELING PRODUCTION OF CORROSION RESISTANT DIFFUSION LAYERS UNDER NON-STATIONARY TEMPERATURE CONDITIONS
}

The paper discusses methods for obtaining alloyed chromium-alloyed coatings and the search for optimal powder mixtures that allow the formation of protective coatings on CCCM under nonstationary temperature conditions. Refractory compounds, primarily carbides, borides, nitrides and silicides, as well as alloys based on them, can be promising materials for applying protective coatings. In addition to protection against oxidation, coatings made of refractory compounds have high hardness and wear resistance. The implementation of the application of protective coatings on highcarbon materials is difficult for a number of reasons. This concerns the low wettability of the carbon surface by refractory metals, low adhesion of the coating to the substrate, which largely depends on the thermophysical properties of the coating, and also the choice of coating components depending on the operating conditions of the finished product. Under non-stationary temperature conditions, it is possible to obtain coatings of various chemical compositions by varying the amount and content of alloying additives. The gas-transport method of applying coatings using UTC makes it possible to obtain CCCM with enhanced physical and mechanical properties, without requiring high energy costs and time.

Keywords: modeling; optimization; variation interval; regression analysis; carbon material; protective coating; corrosion; heat resistance.

В роботі розглянуті методи отримання легованих хромоалітірованних покриттів $i$ пошук оптимальних порошкових шихт, щуо дозволяють формувати захисні покриття на ВВКМ при нестаціонарних температурних умовах. Перспективними матеріалами для нанесення захисних покриттів можуть бути тугоплавкі сполуки, перш за все карбіди, бориди, нітриди $i$ силічиди, а також сплави на їх основі. Крім захисту від окислення покриття з тугоплавких сполук мають високу твердість $і$ зносостійкість. Реалізація нанесення захисних покриттів на високовуглецевих матеріалах утруднена цілим рядом причин. Це стосується не високою можливістю змочування поверхні вуглецю тугоплавкими металами, слабкою адгезією покриття до підкладки, що залежить у багато від теплофізичних властивостей покриття, $i$ також вибору компонентів покриття в залежності від умов роботи готового виробу. При нестаціонарних температурних умовах можливе отримання покриттів різного хімічного складу, варіюючи кількість $і$ зміст легуючих добавок. Газотранспортний метод нанесення покриттів при нестачіонарних температурних умовах, дозволяе отримати ВВКМ 3 підвищеними фізико-механічними властивостями, не вимагаючи високих енерговитрат і часу.

Ключові слова: моделювання; оптимізачія; інтервал варіювання; регресивний аналіз; вуглечевий матеріал; захисне покриття; корозія; термостійкість.

\section{Problem's Formulation}

The practical use of carbon-carbon composite materials (CCCM) in high-temperature processes is very limited due to strong oxidation, as well as erosion and burnout in gas streams. In this regard, the protection of CCCM from oxidation and burnout is an important scientific and technical problem. Refractory compounds, primarily carbides, borides, nitrides and silicides, as well as alloys based on them, can be promising materials for applying protective coatings. In addition to protection against oxidation, coatings made of refractory compounds have high hardness and wear resistance.

\section{Analysis of recent research and publications}

Analysis of the latest research sources and publications. The known methods of obtaining coatings have a number of disadvantages and advantages. The most unacceptable is the fact that when a coating is obtained by impregnating Si from the liquid phase, a chemical interaction occurs with the 
CCCM matrix and a carbide phase is formed, while the mechanical characteristics of the material change, and it should also be taken into account that the carbide component is formed unevenly along section of the main material.

The implementation of the application of protective coatings on high-carbon materials is difficult for a number of reasons. This concerns the low wettability of the carbon surface by refractory metals, low adhesion of the coating to the substrate, which largely depends on the thermophysical properties of the coating, and also the choice of coating components depending on the operating conditions of the finished product. However, to date, many technologies have been developed for the application of protective coatings on carbon materials using the methods of chemical thermal treatment (CHT), as well as impregnation from the liquid phase.

These methods of obtaining coatings have a number of disadvantages and advantages. The most unacceptable is the fact that when a coating is obtained by impregnating Si from the liquid phase, a chemical interaction occurs with the CCCM matrix and a carbide phase is formed, while the mechanical characteristics of the material change, and it should also be taken into account that the carbide component is formed unevenly along section of the main material. In this case, the use of CHT methods is much more priority, but it is characterized by high energy consumption and duration of the process.

One of the most promising methods of applying protective coatings today is the production of diffusion layers under unsteady temperature conditions (UTC) [1-5]. Based on the analysis of the requirements for coatings at CCCM, we chose the diffusion method of surface saturation from the solid phase in an active gas medium in the UTC mode. A distinctive feature of this method is the high quality of the resulting coating surface, short duration, and high temperatures, which are characterized by the composition of the UTC-mixture. Under UTC conditions, it is possible to obtain coatings of various chemical compositions by varying the amount and content of alloying additives.

Many scientists are engaged in the issues of increasing the heat resistance of machine parts. Recently, the use of chromium-alloyed coatings has become widespread. Chromoalloying simultaneous or sequential saturation of metals and alloys with chromium and aluminum - is used mainly to increase wear, heat and corrosion resistance of parts. The main methods of chromium alloying include: solid, from the vapor phase, gas and liquid - simultaneous and sequential, solid simultaneous and from slip [11-12].

Alloying chromium-alloyed coatings with titanium with silicon and boron makes it possible to dramatically increase the operational characteristics and, along with high corrosion and heat resistance, to obtain more versatile layers with high surface hardness, scale resistance and corrosion resistance due to the formation of additional silicon and titanium oxides.

At a content of $<25 \%$ in the mixture, a chromosilicated layer is formed, at $25-40 \% \mathrm{Al}-\mathrm{a}$ chromoaluminosilicated layer, and at a content of $>40 \% \mathrm{Al}$ - an aluminized layer.

Chromoalitization can be carried out in a sequential manner, chromium plated and then aluminized. Simultaneous saturation with chromium and aluminum occurs in aluminothermic mixtures with a $\mathrm{Cr} 2 \mathrm{O} 3$ : $\mathrm{Al}$ ratio of 75-60: 25-40. At a content of $>40 \% \mathrm{Al}$ in the mixture, a predominantly aluminized layer is formed. At a concentration of $<10 \mathrm{Al}$ on the surface of the layer, the mechanical properties of steel do not differ from the properties of the initial one, and at a higher aluminum content, the characteristics of strength, ductility and impact toughness decrease [13-15].

Composite materials based on carbon fibers and carbon matrix are used in industry as:

- High-temperature insulation (asbestos replacement). Pyrocarbon composites: thermal protection, vacuum furnaces, growth units for monosilicon, stress furnaces for silicon carbide products, etc .;

- Anticorrosive coatings and linings;

- Hydroturbine and ship bearings, friction units.

CCCM are widely used in products of rocket and space technology as heat-shielding materials. However, as with any material, CCCM has a number of disadvantages, the main of which is low oxidative resistance at temperatures above $500{ }^{\circ} \mathrm{C}$ [10]. Therefore, special heat-resistant coatings are required for CCCM. Samples for experiments with CCCM (URAL-T22P).

Alloy protective coatings obtained under isothermal conditions have a more porous surface (FeAl phase is present), through which oxygen penetrates to the surface of the CCCM. In comparison 
with the coverings received in isothermal conditions, heat resistance of the alloyed protective coverings received in the UTH conditions is 1,5-1,7 times higher that can be explained also by higher concentration of chromium, aluminum, silicon and titanium which promote formation of protective oxide skin $\mathrm{SiO}_{2}, \mathrm{TiO}_{2}, \mathrm{Cr}_{2} \mathrm{O}_{3}, \mathrm{Al}_{2} \mathrm{O}_{3}$. It was found that protective coatings doped with silicon and titanium, successfully protect carbon materials from oxidation in the temperature range $900-1100{ }^{\circ} \mathrm{C}$.

\section{Formulation of the study purpose}

The purpose of the work is the search for optimal powder SHS-charge, allowing the formation of alloyed chromium-alloyed protective coatings on CCCM in UTC conditions.

\section{Presenting main material}

In this work, CCCM was used for coating. Chemical-thermal treatment was carried out in an open-type reactor $\left(\mathrm{P}=10^{5} \mathrm{~Pa}\right)$ in the temperature range $900-1100{ }^{\circ} \mathrm{C}$ and the total duration of isothermal holding up to $60 \mathrm{~min}$. A mixture of powders with a dispersion of $100-400$ microns was used as a saturating medium, powders of these materials: $\mathrm{Cr}_{2} \mathrm{O}_{3}, \mathrm{Al}_{2} \mathrm{O}_{3}, \mathrm{Al}, \mathrm{Ti}, \mathrm{Si}, \mathrm{J}_{2}, \mathrm{NH}_{4} \mathrm{Cl}$. In order to search for the compositions of SHS powder mixtures providing high corrosion resistance, a full factorial experiment was used.

Table 1. Results of regression analysis of experimental data

\begin{tabular}{|c|c|}
\hline \multirow{2}{*}{ Parameter } & Response functions \\
\cline { 2 - 2 } & $\mathrm{Y}_{1}$ \\
\hline $\mathrm{b}_{0}$ & 60,311 \\
\hline $\mathrm{b}_{1}$ & $-0,6$ \\
\hline $\mathrm{b}_{2}$ & 4,1 \\
\hline $\mathrm{b}_{3}$ & $-0,6$ \\
\hline $\mathrm{b}_{4}$ & 0,1111 \\
\hline $\mathrm{b}_{5}$ & $-3,3889$ \\
\hline $\mathrm{b}_{6}$ & 4,111 \\
\hline $\mathrm{b}_{7}$ & 2,375 \\
\hline $\mathrm{b}_{8}$ & 0,375 \\
\hline $\mathrm{b}_{9}$ & 2,125 \\
\hline$\Delta \mathrm{b}$ & 2,02 \\
\hline $\mathrm{t}-$ criterion & 2,77 \\
\hline $\mathrm{F}-$ criterion & $2,84<6,16$ \\
\hline
\end{tabular}

The choice of the optimal composition of the mixture for carrying out SHS - processes under conditions of thermal self-ignition was carried out on the basis of the results of studies of the thermal picture of the SHS process and the physical and mechanical properties of protective coatings [6-9]. The following were chosen as independent variables:, the content of the chromium component, silicon, titanium and aluminum in the SHS-mixture. Steel 50 was chosen as the starting material. The process activators are $\mathrm{J}_{2}$ and $\mathrm{NH}_{4} \mathrm{~F}$ for all systems. To obtain a $100 \%$ composition of SHS powder mixtures, $\mathrm{Al}_{2} \mathrm{O}_{3}$ was used as the final product.

Checking the adequacy of the models shows that they can be used to predict the values of the response functions for any values of the factors between the upper and lower levels.In order to determine the mode and SHS-compositions that provide optimal indicators of heat resistance of coatings, three-dimensional graphical dependences were built (Fig. 1).

Based on the results of mathematical modeling, the optimal content of alloying elements was established when applying corrosion-resistant coatings on the CCCM. From the analysis established that the rational titanium content of $20 \%$ of the mass. As the aluminum content increases, the amount of mass loss decreases. The rational content of aluminum is $14-15 \%$ of the mass. As a result, the optimal composition for applying corrosion-resistant coatings is: $25 \% \mathrm{CC}+15 \% \mathrm{Al}+20 \% \mathrm{Ti}+35 \%$ $\mathrm{Al}_{2} \mathrm{O}_{3}+2 \% \mathrm{I}_{2}+3 \% \mathrm{NH}_{4} \mathrm{Cl}$. 


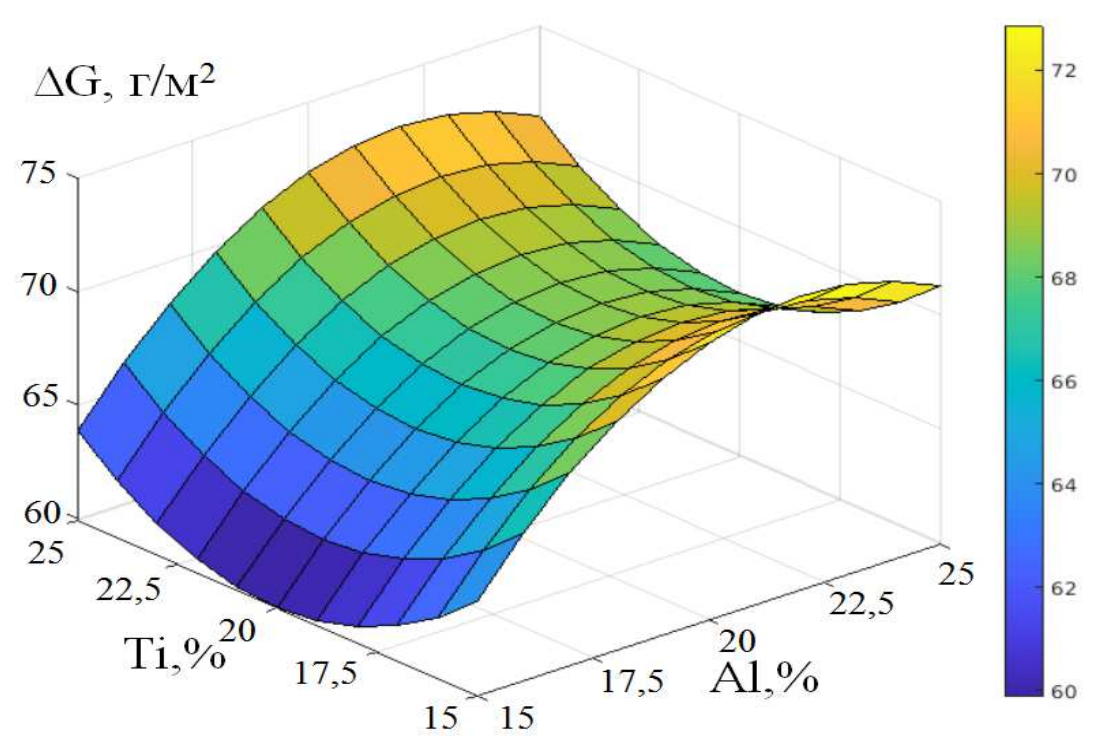

Fig. 1. Optimization of heat resistance for the $\mathrm{Cr}-\mathrm{Al}-\mathrm{Ti} /$

As a result of calculations, the following equations were obtained:

$$
\begin{gathered}
\mathrm{Y}_{1}=60,311-0,6 \mathrm{X}_{1}+4,1 \mathrm{X}_{2}-0,6 \mathrm{X}_{3}+0,1111 \mathrm{X}_{1}^{2}-3,3889 \mathrm{X}_{2}^{2}+4,1111 \mathrm{X}_{3}^{2}+ \\
+2,375 \mathrm{X}_{1} \mathrm{X}_{3}+0,375 \mathrm{X}_{1} \mathrm{X}_{3}+2,125 \mathrm{X}_{2} \mathrm{X}_{3} .
\end{gathered}
$$

The analysis of the reactions occurring during the UTC process, as well as the results of experiments and metallographic studies, made it possible to obtain a scheme for the formation of protective coatings. The process of formation of protective coatings in the thermal autoignition mode can be conventionally divided into five stages: inert heating of the UTC mixture to the autoignition temperature, thermal autoignition, heating of parts, isothermal holding and cooling.

At the initial stage (stage 1), inert heating of the mixture occurs. When used as a supplier of a diffusing element - boron or silicon - the formation of a boron or silicified layer is observed.

At stage 2 - the stage of thermal autoignition, the autoignition temperature rises at a rate of $200-400{ }^{\circ} \mathrm{C} / \mathrm{s}$ to the maximum value. At this stage, along with the formation of active boron and silicon atoms, reactions of the formation of elemental chromium and their combination with carriers (fluorine, chlorine and iodine) take place, with the formation of volatile halides. If the activation energy of the interaction of the charge elements with the support is less than the activation energy of the main reduction process, then the formation of volatile halides will proceed quasi-stationary as the main reaction proceeds. If the autoignition temperature is lower than the temperature of the onset of intense formation of a volatile halide, then for this case, the formation of halides occurs only at the stage of unsteady temperature rise. When the maximum temperature is reached, which converts the pyrolysis temperature of chromium diiodide, silicon, its rapid decomposition occurs.

At 3 stages - the stage of warming up the products, the temperature drops to the process temperature $\mathrm{Tp}$ due to the reception of the released heat by the products. Active atoms begin to diffuse into the substrate and the carbide phases are doped with titanium and silicon.

At the 4th stage, the stage of isothermal holding, a constant diffusion flow of the formed active atoms of chromium, aluminum, silicon and titanium is formed. The diffusion layer increases and the chromium-alloyed layers are doped with boron and silicon. With increasing isothermal exposure, the layer thickness increases. The growth of the layer obeys a parabolic law.

At the 5th stage - the cooling stage, a diffusion layer is formed with a lower intensity due to a decrease in the diffusion coefficient of silicon and boron due to a drop in temperature. The layer consists of two phases: the outer one, which is chromium borides and silicides, and the inner one, the carbide phase. 
For tests of heat resistance, flat samples were used (thickness $=3 \mathrm{~mm}$, length $=30 \mathrm{~mm}$, width $=$ $20 \mathrm{~mm}$ ). The test temperature was: $90-1100^{\circ} \mathrm{C}$. Weighing of the tested samples was carried out every 5 hours of testing, on an analytical balance VLR -200 with an accuracy of $10^{-4} \mathrm{~g}$. The total test time was 25 hours. The best heat resistance among the considered coatings have chromiumalumosilicated coatings. Their heat resistance is $2.5-3.3$ times higher than that of uncoated samples.

\section{Conclusions}

Based on the results of mathematical modeling, the optimal content of alloying elements was established when applying corrosion-resistant coatings on the CCCM. From the analysis established that the rational titanium content of $20 \%$ of the mass. As the aluminum content increases, the amount of mass loss decreases. The rational content of aluminum is $14-15 \%$ of the mass. The rational content of aluminum is $14-15 \%$ of the mass. As a result, the optimal composition for applying corrosion-resistant coatings is: $25 \% \mathrm{CC}+15 \% \mathrm{Al}+20 \% \mathrm{Ti}+35 \% \mathrm{Al}_{2} \mathrm{O}_{3}+2 \% \mathrm{~J}_{2}+3 \% \mathrm{NH}_{4} \mathrm{Cl}$.

When studying the influence of the mode of thermal self-ignition, it was found that the optimal process temperature is $1050{ }^{\circ} \mathrm{C}$, the duration of exposure at this temperature -60 minutes. The best heat resistance among the considered coatings have chromium-alumosilicated coatings. Their heat resistance is 2.8-3.5 times higher than that of uncoated samples. Research the heat resistance of the obtained protective coatings, suggests an increase in the heat resistance of machine parts and mechanisms by $1.5-1.9$ times. The gas-transport method of applying coatings using UTC makes it possible to obtain CCCM with enhanced physical and mechanical properties, without requiring high energy costs and time.

\section{References}

[1] Chuen-Chien Lee Fuzzy Logic in Control Systems: Fuzzy Logic Controller, Part I1. IEEE Transactions on systems, man, and cybernetics. 1990/3. - Vol. 20, № 2. - P. 404-418.

[2] N.V. Trefilova Analysis of modern methods of applying protective coatings // Modern high technologies. - 2014. - No. 10. - P. 67-67

[3] Lakhtin Yu. M. Metallurgy and heat treatment of metals. / Yu. M. Lakhtin // - M .: Metallurgy, $1993 .-448 \mathrm{p}$.

[4] Merzhanov A.G. Combustion Processes and Synthesis of Materials, Ed. I.T. Telepy, A.P. Khachoyan. Chernogolovkam ISMAN, 1998. - 512s.

[5] Sereda B.P. Current state and prospects for the development of technologies for applying protective coatings in SHS conditions / B.P. Sereda, I.V. Kruglyak, V.I. Ivanov // New materials and technologies in metallurgy and mechanical engineering. - 2004. - No. 1. - S. 88-93.

[6] Sereda B.P. Surface hardening of materials: Monograph / Sereda B.P., Kalinina N.E., Kruglyak I.V. - Zaporozhye: RVV ZDIA, - 2004. - $230 \mathrm{p}$.

[7] Khusainov M.A. Chemical gas-phase-diffusion crystallization and structure of coatings from carbides of transition metals IVa - Va subgroups on graphite / M.A. Khusainov, G.M. Demyashev, M.M. Myshlyakov // Izv. Academy of Sciences of the USSR. Metals. - 1991. - No. 4. - S. 152157.

[8] Protective coatings for structural carbon-graphitic materials / V.S. Dergunova, G.A. Kravetsky, A.V. Emyashev [et al.] // Protective coatings. - L .: Nauka, 1978 .-- S. 114-117.

[9] Dzyadykevich Yu.V. Ways to protect graphite materials from oxidation / Yu.V. Dzyadykevich, V.E. Oiler // Powder metallurgy. - 1996. - № 3/4. - P. 41-47.

[10] Sereda B.P. Investigation of the kinetics of the formation of protective coatings on carbon materials in the conditions of SHS / B.P. Sereda, Yu.A. Belokon, Yu.V. Bondarenko // Sb. scientific works "Construction, materials science, mechanical engineering". Issue. 45, Part 2, Starodub readings 2008, Dnepropetrovsk. - P. 31-36.

[11] Yagodkin Yu.D. Heat-resistant coatings (review) / Yu.D. Yagodkin, VS Terentyeva // Results of science and technology. Ser. Metallurgy and heat treatment. - 1991. - №25. - P. 183-254.

[12] Chemical and thermal treatment of metals and alloys. Directory. Borisenok G.V, Vasiliev L.A., Voroshnin L.G. et al. M .: Metallurgy, 1981. - 424 p. 
[13] Sereda B.P., Babachenko E.V., Sereda D.B. Formation of heat-resistant alloys on the basis of intermetallic compounds obtained under SHS conditions. Construction, materials science, mechanical engineering: Sat. scientific works. Issue. 74 - Dn-vsk., PGASA, 2014.- P.29-33.

[14] Sereda B.P., Sereda D.B. Modeling Deformation in Material Processing and Laws of Phasic by SHS Pressing Intermetallics Alloys. Material science and technology 2015. Conference and Exhibition. Columbus, OH, USA. 1821p. P.611-617

[15] Sereda B.P. Theory of structure of liquid, crystalline and amorphous state of matter. Textbook with the stamp of the Ministry of Education and Science, stamp № 1.4 / 8-G-80.-Zaporizhzhya RVV ZDIA, - 2008. - 238 p.

\section{МОДЕЛЮВАННЯ КОРОЗІЙНОСТІЙКИХ ДИФУЗІЙНИХ ШАРІВ ПРИ НЕСТАЩІОНАРНИХ ТЕМПЕРАТУРНИХ УМОВ \\ Середа Д.Б.}

\section{Реферат}

В роботі розглянуті методи отримання легованих хромоалітірованних покриттів і пошук оптимальних порошкових шихт, що дозволяють формувати захисні покриття на ВВКМ при нестаціонарних температурних умовах. Перспективними матеріалами для нанесення захисних покриттів можуть бути тугоплавкі сполуки, перш за все карбіди, бориди, нітриди і силіциди, а також сплави на їх основі. Крім захисту від окислення покриття з тугоплавких сполук мають високу твердість і зносостійкість. Відомі методи отримання покриттів мають ряд недоліків і переваг. Найбільш неприйнятним $\epsilon$ той факт, що при отриманні покриття просоченням кремнієм Si з рідкої фази, відбувається хімічна взаємодія з матрицею ВВКМ і утворюється карбідна фаза, при цьому змінюються механічні характеристики матеріалу, а так само слід враховувати той факт, що карбідна складова утворюється нерівномірно по перетину основного матеріалу. Реалізація нанесення захисних покриттів на високовуглецевих матеріалах утруднена цілим рядом причин. Це стосується не високою можливістю змочування поверхні вуглецю тугоплавкими металами, слабкою адгезією покриття до підкладки, що залежить у багато від теплофізичних властивостей покриття, і також вибору компонентів покриття в залежності від умов роботи готового виробу.

При нестаціонарних температурних умовах можливе отримання покриттів різного хімічного складу, варіюючи кількість і зміст легуючих добавок. Газотранспортний метод нанесення покриттів при нестаціонарних температурних умовах, дозволяє отримати ВВКМ 3 підвищеними фізико-механічними властивостями, не вимагаючи високих енерговитрат і часу.

3 метою пошуку складів порошкових шихт, що забезпечують високу коррозіонную стойкость i жаростійкість, використовувався повний факторний експеримент. Вибір оптимального складу суміші для проведення $\mathrm{CBC}$ - процесів в умовах теплового самозаймання проводили на підставі результатів досліджень теплової картини процесу i фізико-механічних властивостей захисних покриттів.

Перевірка адекватності моделей показує, що їх можна використовувати для прогнозування значень функцій відгуку при будь-яких значеннях факторів, що знаходяться між верхнім і нижнім рівнями. 3 метою визначення режиму і складу шихти, що забезпечують отримання оптимальних показників жаростійкості покриттів будували тривимірні графічні залежності, та отримано оптимальний склад шихти при насичені при нестаціонарних температурних умовах.

\section{Література}

1. Chuen-Chien Lee (1990) Fuzzy Logic in Control Systems: Fuzzy Logic Controller, Part I1. IEEE Transactions on systems, man, and cybernetics. 1990/3. - Vol. 20, № 2. - P. 404-418. 
2. Трефилова Н.В. Анализ современных методов нанесения защитных покрытий// Современные наукоемкие технологии. - 2014. - № 10. - С. 67-67

3. Лахтин Ю.М. Металловедение и термическая обработка металлов. / Ю.М. Лахтин // - М.: Металлургия, 1993. - 448 с.

4. Мержанов А.Г. Процессы горения и синтез материалов/Под ред. И.Т. Телепы, А.П. Хачояна. Черноголовкам ИСМАН, 1998. 512c.

5. Середа Б.П. Современное состояние и перспективы развития технологий нанесения защитных покрытий в условиях СВС / Б.П. Середа, И.В. Кругляк, В.И. Иванов // Новые материалы и технологии в металлургии и машиностроении. - 2004. - №1. - С. 88-93.

6. Середа Б.П. Поверхневе зміцнення матеріалів: Монографія / Середа Б.П., Калініна Н.Є., Кругляк І.В. - Запоріжжя: РВВ ЗДІА, - 2004. - 230 с.

7. Хусаинов М.А. Химическая газофазно-диффузионная кристаллизация и структура покрытий из карбидов переходных металлов IVa - Va подгрупп на графите / M.A. Хусаинов, Г.М. Демяшев, М.М. Мышляков // Изв. АН СССР. Металлы. - 1991. - №4. - С. 152-157.

8. Защитные покрытия конструкционных углеграфитовых материалов / В.С. Дергунова, Г.А. Кравецкий, А.В. Емяшев [и др.] // Защитные покрытия. - Л.: Наука, 1978. - С. 114-117.

9. Дзядикевич Ю.В. Шляхи захисту графітових матеріалів від окислення (Оглад) / Ю.В. Дзядикевич, В.Е. Олійник // Порошковая металлургия. - 1996. - № 3/4. - С. 41-47.

10. Середа Б.П. Исследование кинетики формирования защитных покрытий на углеродных материалах в условиях СВС/ Б.П. Середа, Ю.А. Белоконь, Ю.В. Бондаренко // Сб. науч. трудов “Строительство, материаловедение, машиностроение”. Вып. 45, Ч.2, Стародубовские чтения 2008, Днепропетровск. - С. 31-36.

11. Ягодкин Ю.Д. Жаростойкие покрытия (обзор) / Ю.Д. Ягодкин, В.С. Терентьева // Итоги науки и техники. Сер. Металловедение и термическая обработка. - 1991. - № 25. - С. 183-254.

12. Химико-термическая обработка металлов и сплавов. Справочник. Борисенок Г.В., Васильев Л.А., Ворошнин Л.Г. и др. М.: Металлургия, 1981. 424 с.

13. Середа Б.П., Бабаченко Є.В., Середа Д.Б. Утворення жароміцних сплавів на основі інтерметалідних сполук, отриманних в умовах СВС. Строительство, материаловедение, машиностроение: Сб. науч. трудов. Вып. 74 - Дн-вск., ПГАСА, 2014.- С.29-33.

14. Sereda B., Sereda D. Modeling Deformation in Material Processing and Laws of Phasic by SHS Pressing Intermetallics Alloys. Material science and technology 2015. Conference and Exhibition. Columbus, OH,USA. 1821p. P.611-617

15. Середа Б.П. Теорія будови рідкого, кристалічного та аморфного стану речовини. Навчальний посібник з грифом МОНУ, гриф № 1.4/8-Г-80.-Запоріжжя РВВ ЗДІА, - 2008. $238 \mathrm{c}$. 